\title{
Handbook for sustainable development: Integrated Water Resources Management in Hanoi, Vietnam
}

\author{
Sổ tay hướng dẫn về phát triển bền vũng: Quản lý tổng hợp tài nguyên nước tại \\ Hà Nội, Việt Nam
}

Short communication

Stefan, Catalin ${ }^{*}$; Fuchs, Lothar ${ }^{2}$; Röstel, Gunda ${ }^{3}$; Werner, Peter ${ }^{1}$

${ }^{1}$ Institute of Waste Management and Contaminated Site Treatment, Technische Universität Dresden, Pratzschwitzer Str. 15, 01796 Pirna, Germany; ${ }^{2}$ Institute for Technical and Scientific Hydrology, Engelbosteler Damm 22, 30167 Hanover, Germany; ${ }^{3}$ Dresden Drainage and Sewerage Company, Scharfenberger Str. 152, 01139 Dresden, Germany

\begin{abstract}
The handbook presented in this paper summarises the results of the research initiative "International Water Research Alliance Saxony" (IWAS). The subproject "IWAS Vietnam" (Phase I, October 2008 - December 2010) focuses on the model region "South-East Asia" with emphasis on Vietnam. The project started as a joint research initiative between German and Vietnamese organisations and included contributions from academic, private and public sector in both countries. The handbook was compiled by the Technische Universität Dresden (project coordination), the Institute for Technical and Scientific Hydrology and Dresden Drainage and Sewerage Company, with substantial contributions from Vietnamese partners.
\end{abstract}

Sổ tay hướng dẫn trong bài viết này tóm lược các kết quả của sáng kiến nghiên cứu tì "Liên minh Nghiên cứu ngành nuớc quốc tế bang Saxony" (IWAS). Dụ án nhánh "IWAS Việt Nam" (giai đoạn 1, 10/2008 - 12/2010) tập trung vào khu vưc Đông Nam Á với trọng tâm là Việt Nam. Dự án khởi động nhu một sáng kiến liên kết nghiên cứu giữa các tổ chức của CHLB Đức và Việt Nam với sụ đóng góp tù các đơn vị tu nhân, nhà nước và trương đại học của cả hai quốc gia. Quyển sổ tay này được biên soạn bởi Đại học Kỹ thuật Dresden (co quan điều phối dụ án), Viện Công nghệ và Khoa học Thủy văn, và Công ty Thoát nước Dresden, cùng với sụ đóng góp quan trọng của các đối tác Việt Nam.

Keywords: integrated water resources management; handbook; wastewater management; drainage; groundwater recharge; IWAS; Hanoi; Long Bien

\section{Motivation}

In Vietnam, as well as in other Southeast Asian countries, the rapid population growth is accompanied by severe conflicts and great challenges: dense urbanisation and rapid industrialisation with resulting exposure and pollution of the vital water resources, accompanied by climate change with extreme weather conditions. In megacities like Hanoi, the high population growth and the extreme population density triggers continuous expansion of residential areas merging adjacent provinces and districts into the metropolitan area. The downside of this rapid development is the impossibility of providing timely and adequate services to population and industry, works on infrastructure being delayed or partially inexistent. Moreover, the solutions adopted are often too short-term problem- oriented and not following a sustainable approach in terms of integrated water resources management. The long-term consequences are reflected in various aspects, from severe flooding to, for example, aquifer depletion and subsidence of land surface caused by overexploitation of groundwater resources.

To overcome these challenges, consequent priorities have to be set for this topic. To find appropriate sustainable solutions for this complex task, an integrated concept and design for the protection of water resources is needed. This concept should comprise an integrated guideline for the development of the entire water resources of a city or a part of it: surface water, rainwater, sewage, drinking water, and groundwater. The aim is to examine, provide guidelines and make a conceptual design in order to cre- 
ate an urban water landscape with a clear connection between the underlying structures of topography, hydrology and soils as the major structuring foundation of urban form, including the use of catchments as the basis for physical planning and regulation.

For this purpose, the Long Bien urban district of the capital Hanoi has been chosen as a model district for implementation of the project's objectives due to its specific environmental and anthropogenic characteristics: The district is situated in northern Hanoi at the convergence of two rivers (Red River and Duong River), with an area of about 6,000 ha and over 200,000 inhabitants, with estimated 350,000 inhabitants by 2020 . Due to its geographical position and rapid development, Long Bien district will soon become one of the centres for trade, service, and transportation (road, rail and airway) for connecting Hanoi with other provinces in the North of Vietnam. As the old urban areas and some new unprompted residential estates have not yet been developed with a systematic drainage system, flooding occurs in some areas. Wastewater of many residential estates, factories, manufactories, and hospitals is not drained and sufficiently treated decentralised by septic tanks or centralised in a treatment plant. Hence the pollution risk from wastewater is high and affects the welfare of people.

\section{Objectives}

The overall objective of IWAS in Vietnam is the development of a sustainable drainage concept based on the existing master plan for Long Bien district and its integration into the existing local water cycle in respect to: supporting further urban development, avoidance or minimisation of flood, conservation of water resources and improvement of the quality of surface and groundwater. This will be achieved by applying three main concepts considered as pillars of the IWAS-Vietnam initiative:

\subsection{Sustainable urban drainage}

With respect to local requirements (climatic conditions, population growth, estimated land use, etc.), the optimisation and further development of the existing master plan was done in collaboration with the local Sewerage and Drainage Company and responsible public authority. The general drainage concept relies on sustainability criteria, being mainly based on strict separation of sewage and rainwater in newly developed areas, adequate treatment of sewage and polluted rainwater, implementation of infiltration and rainwater harvesting facilities, as well as restoration or construction of ecologically valuable open channels and ditches. The conceptual design for domestic sewage includes the sewage network, pumping stations and treatment facilities. A cost-benefit analysis helped to estimate the necessary number, location and efficiency of wastewater treatment plants. In addition, a sustainable rainwater drainage system making use of the existing urban landscape consists of a network of infiltration ponds, canals, open ditches, pumping stations, etc. The special conditions that have to be considered in Hanoi (heavy precipitation, high population development index) imposed customised, flexible solutions suitable for a step- by-step realisation and implementation of project requirements.

\subsection{Resources conservation}

The general drainage system proposed was amended by technical measures aimed at the realisation of an integrated resource management by using natural processes for the treatment of urban water and its integration into the urban cityscape. The solution proposed consists in artificial replenishment of groundwater using mostly rainwater of adequate quality. Besides direct economical benefits (taking advantage of the natural processes for water purification in the subsurface), the concept will overcome major problems related to lowering of the groundwater table caused by overexploitation. While the water demand in the Long Bien district, as in the whole city of Hanoi, is assumed to closely follow the demographic trend, artificial recharge of groundwater represents a sustainable method to ensure adequate water supply to a continuously growing population. On a bigger scale, the method offers short- and long-term subsurface water storage, a solution considered preferable compared to surface storage (in lakes and ponds) due to safety reasons (less exposure to human activities and negative environmental factors). By closing the water cycle (recharge and discharge units) it also permits a better management of resources in terms of sustainability at local level, with a positive impact in the long term.

\subsection{Capacity development}

The sustainable concepts proposed within the project cannot be implemented in practice without a solid longterm development of local capacity in terms of human resources, organisational development, and institutional and legal framework development. The identified issues vary greatly from organisational aspects (e.g. inappropriate division of responsibilities between institutions, financial dependence of public service providers on local governments) to human resources (e.g. inadequate qualifications and insufficient number of staff, difficulties in implementing new technologies). Moreover, a limited awareness at community level regarding the importance of provided services reduces the providers' capacity to improve and further develop the services offered.

\section{About the handbook}

The handbook 'Integrated Water Resources Management in Vietnam: a handbook for sustainable approach" has been designed with two aims:

1. To provide an overview about the results of the research project 'IWAS Vietnam'

2. To provide technical guidelines about integrated water management in new urban areas under specific conditions. Having both a particular and a general character, the resulting guidelines will also be transferable to similar regions of $\mathrm{Vi}$ etnam and other Southeast Asian countries. 
The handbook is structured on six parts as following:

\subsection{Introduction}

Part 1 contains general information about the research project whose results have permitted the realisation of the present handbook, including motivation and reasons to act, overall and specific project objectives, as well as a very concise description of the handbook's content.

\subsection{Description of study area}

The second part provides a general description of the focus area with emphasis on localisation, climatic conditions, geology and hydrogeology, social situation and a brief outline on the area's development over the past years.

\subsection{Analysis of the water management situa- tion}

The analysis done in part 3 refers to the physical characteristics and functionality of main surface water bodies as well as interconnections with the local water system and subsurface reservoirs. The part 3 provides also an assessment of the main technological lines for treatment of municipal sewage and sludge as included in the present master plan for the district development.

\subsection{Integrated water management}

The fourth part brings into focus the elements of integrated water management with special emphasis on the sustainable management of three main components: rainwater, wastewater and groundwater. Several technical solutions are briefly presented for each section with description of technical and site-specific applicability as well as suitability and advantages analysed on a case-by-case basis.

\subsection{Exemplary measures and concepts}

After the general screening of available solutions made in part 4 it follows the more practical, applicative part 5 where exemplary solutions are provided on a specific project framework. At first, general rainwater balance scenarios have been evaluated based on specific land use criteria. These included above-surface approach as well as infiltration into subsurface and thus artificial augmentation of groundwater reservoirs in respect to both qualitative and quantitative aspects. As important component of the urban development, the district's drainage system has been upgraded and special recommendations have been made for both sewage and sludge management. For better exemplification, the solutions are applied to a small pilot area within the Long Bien district.

\subsection{Conclusions and recommendations}

The last chapter of the handbook wraps-up the solutions presented and emphasis the role of each component in the integrated water management concept. Suggestions are also made about the potential transfer of handbook results to regions with comparable boundary conditions from Vietnam or other similar regions in South-East Asia.

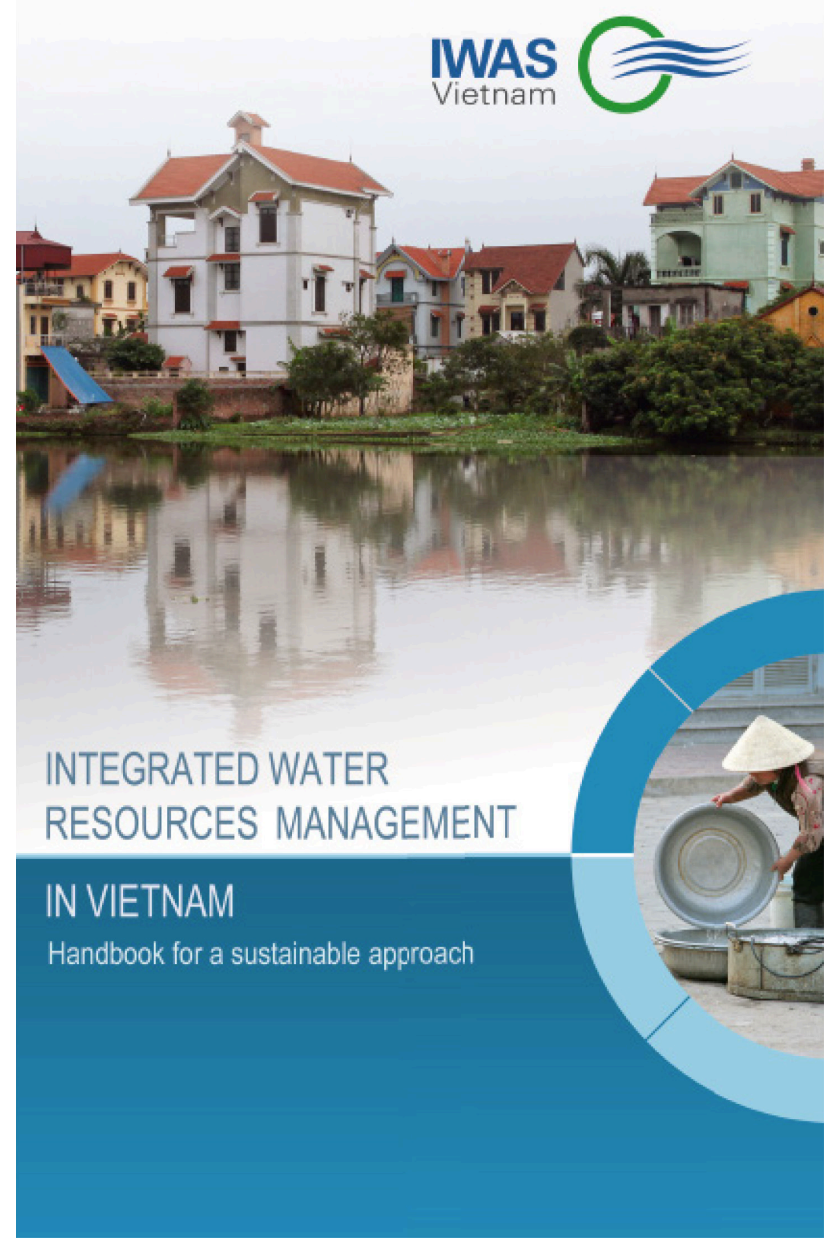

Figure 1. Handbook cover page

\section{Acknowledgements}

The compilation of the handbook was sponsored by the German Federal Ministry of Education and Research (BMBF) within the framework of the project International Water Alliance Saxony (IWAS Vietnam, reference number 02WM1028).

\section{References}

[1] Werner, P., Röstel, G., Fuchs, L., Stefan, C. 2011. Integrated Water Resources Management in Vietnam. Handbook for a Sustainable Approach. ISBN 978-3-934253-65-0, Dresden, Germany 